\title{
The infection of ectoparasitic protozoa on farmed Nile tilapia (Oreochromis niloticus) at three reservoirs in Central Java, Indonesia
}

\author{
WALEED SULIMAN KRPOS KOLIA ${ }^{1, \downarrow}$, SUNARTO ${ }^{1,2,3}$, TETRI WIDIYANI $^{1,2}$ \\ ${ }^{1}$ Bioscience Graduate Program, School of Graduates, Universitas Sebelas Maret. J1. Ir. Sutami 36A, Surakarta 57126, Central Java, Indonesia. \\ Tel.: +62-271-669376, Fax.: +62-271-663375, ^email: waleed.krpos@gmail.com \\ ${ }^{2}$ Department of Biology, Faculty of Mathematics and Natural Sciences, Universitas Sebelas Maret. Jl. Ir. Sutami 36A, Surakarta 57126, Central Java, \\ Indonesia \\ ${ }^{3}$ Department of Environmental Science, Faculty of Mathematics and Natural Sciences, Universitas Sebelas Maret. J1. Ir. Sutami 36A, Surakarta 57126, \\ Central Java, Indonesia
}

Manuscript received: 13 February 2021. Revision accepted: 25 March 2021.

\begin{abstract}
Kolia WSK, Sunarto, Widiyani T. 2021. The infection of ectoparasitic protozoa on farmed Nile tilapia (Oreochromis niloticus) at three reservoirs in Central Java, Indonesia. Biodiversitas 22: 1975-1980. There is an expansion of fish culture in Indonesia, but there is a dearth of information on the parasitic infecting cultured fish. This study was conducted to investigate the occurrence of ectoparasitic protozoans on farmed Nile tilapia (Oreochromis niloticus) at three reservoirs (i.e., Cengklik, Mulur, and Gajah Mungkur) in Central Java, Indonesia, and to determine the prevalence, mean abundance, and mean intensity of such parasites. A total of 189 samples were collected from different cages. The sex of the fishes was determined and their lengths and weights were measured. The gills, fins, and skin were examined for ectoparasitic protozoa using a light microscope. Among the examined fishes, 146 samples were infected at the rate of $77.2 \%$. Mulur reservoir had the highest prevalence rate with $90.4 \%$, followed by Cengklik and Gajah Mungkur with $82.5 \%$ and, 58.7\%, respectively. We found female fishes were more susceptible to the infection than males. Seven parasite species were identified, namely: Tetrahymena corlissi, Apiosoma spp., Trichodina spp., Cryptobia spp., Chilodonella spp., Ambiphrya spp., and Ichthyophthirius multifiliis. The protozoan parasite Trichodina spp. recorded the highest prevalence, mean intensity, and mean abundance among all the other protozoan species at the three reservoirs. The results provided a significant difference at $(\mathrm{p}<0.01)$ in the total number of parasites among the reservoirs. Despite the parasite infection, the physical and chemical parameters of the water of the three reservoirs were within the recommended range for the culture of Nile tilapia under the cage systems.
\end{abstract}

Keywords: Ciliated protozoa, ectoparasitic, fish disease, floating cages, Nile tilapia, Oreochromis niloticus

\section{INTRODUCTION}

Aquaculture is the fastest-growing important sector in food production that provides a substantial contribution to food security and job opportunities. The trades involved in aquaculture-inputs, and products constitute resources that stimulate economic growth and poverty reduction (Santos et al. 2020). According to the data released by FAO, Indonesia is the second-largest fish producer in the world after China, with an estimated production of 20.9 million tons per year. The sector contributes to $21.0 \%$ of the GDP generated from agriculture, which is equivalent to $3.1 \%$ of the national GDP and creates 6.4 million direct jobs (Tran et al. 2017). The fish consumption per capita is increasing and the country is among high fish consumers with an annual per capita consumption rate between $30-50 \mathrm{~kg}$ (Santos et al. 2020).

While the consumption of fish, including Tilapia, continues to increase, the emergence of new diseases threatens aquaculture development. In particular, the incidence of parasitic diseases on fish is an issue that should be carefully considered. The ectoparasitic protozoa are ubiquitous in the aquatic environment and can cause economic loss in fish farms as a result of host mortality (Molnar et al. 2019). Such diseases have been the problems for aquaculture commodities including in Nile tilapia (Oreochromis niloticus).

Protozoan parasites comprise one of the foremost pathogens negatively influencing the farmed fish especially Nile tilapia. In Nile tilapia, several protozoan parasites are common to attack the fish, including Ichthyobodo necatrix, Cichlidogyrus, Gyrodactylus, Dactylogyrus, Contracaecum sp. Tetrahymena corlissi, Apiosoma spp., Trichodina spp., Cryptobia spp., Chilodonella spp., Ambiphrya spp., and Ichthyophthirius multifiliis (Bruno et al. 2006; Arguedas et al. 2017).

Parasite infestation increases in intensive culture systems due to the high density of fish, and it becomes difficult to eradicate as the fish density increases (Kuchta et al. 2018). In this situation, host fish can become a pathogen path for infection to other fishes (Suliman and Al-Harbi 2016). Moreover, protozoan parasites are among the foremost pathogenic that infects fishes and cause mortality under poor environmental conditions and high stocking density. This problem is one of the most significant setbacks in achieving maximum production per unit area of fish cage culture (Biu et al. 2014).

Symptoms of an infestation vary greatly from one species of fish to another and from one parasite to another. Depending on the species of parasite considered and the 
health status of the animals, the prevalence and intensity of the infestation, the presence of parasites in a farm will have different impacts (Bruno et al. 2006; Pantoja et al. 2012; Arguedas et al. 2017; Indahsari et al. 2019).

The pooling of protection and control methods often proves to be beneficial. Exchanges information between farmers, producers, and experts working in fish production chains can be fruitful because parasite problems often have unknown impacts that other operators have not yet experienced. While anecdotal evidence of parasite problems in aquaculture is sometimes available and shared among stakeholders, there have been limited studies to help to solve such problems due to the low scientific capacity and the lack of necessary infrastructure for research (Mitiku et al. 2018).

This study aims to investigate the occurrence of ectoparasitic protozoa on farmed Nile tilapia (O. niloticus) at three reservoirs in Central Java, Indonesia, and to determine the prevalence, mean abundance, and mean intensity of such parasites.

\section{MATERIALS AND METHODS}

\section{Study period and area}

The study was conducted from July to November 2020 at three different reservoirs in Central Java Province, Indonesia namely; Cengklik, Mulur, and Gajah Mungkur. The Cengklik reservoir is located in Boyolali District at geographical coordinates of S $07^{\circ} 31^{\prime} 1.11^{\prime \prime}$ and $\mathrm{E}$ $110^{\circ} 43^{\prime} 58.22^{\prime \prime}$. The Gajah Mungkur reservoir is located in Wonogiri District at S $07^{\circ} 85^{\prime} 50.76^{\prime \prime}$ and E 11091'19.74". The Mulur reservoir is located in Sukoharjo District at $\mathrm{S}$ $07^{\circ} 68^{\prime} 86.13^{\prime \prime}$ and E $110^{\circ} 87^{\prime} 73.51^{\prime \prime}$.

\section{Collection of fish specimens}

Fish specimens were collected from three different zones at each reservoir using a random method. A total of 189 specimens of Nile tilapia (O. niloticus) were collected using scoop nets. The samples were then stored immediately in plastic containers and transported to the Laboratory of Biology, Faculty of Mathematics and Natural Science (FMIPA), Sebelas Maret University, Surakarta, Indonesia for identification and screening of ectoparasitic protozoa.

\section{Sex determination and measurements of fish samples}

Fish samples were identified using the guide provided by Molnar et al. (2019). A ruler was used to measure the total length (TL) and standard length (SL) in (cm), while an electronic weight balance was used to measure the weight of the fish samples in grams. The sex of the fish was determined by external examination and internal examination of the testes and ovaries as described by Bruno et al. (2006).

\section{Preparation of the samples and examination for Ecto- protozoan parasites}

The external parts of the fish samples (fins, skin, and gills) were carefully examined and smears were taken from these parts and spread on a dry clean glass slide. Then the smears were dried in the air and then fixed with absolute methanol alcohol for 10 minutes. After that, the smears were stained with freshly prepared Giemsa stained for 30 minutes. Then smears were rinsed under tap water and left to air dry. Smears were examined for ectoparasitic protozoa under a light microscope connected with a camera Nikon. The identification of parasites was carried out following the protocol prescribed by Bruno et al. (2006) and Kuchta et al. (2018).

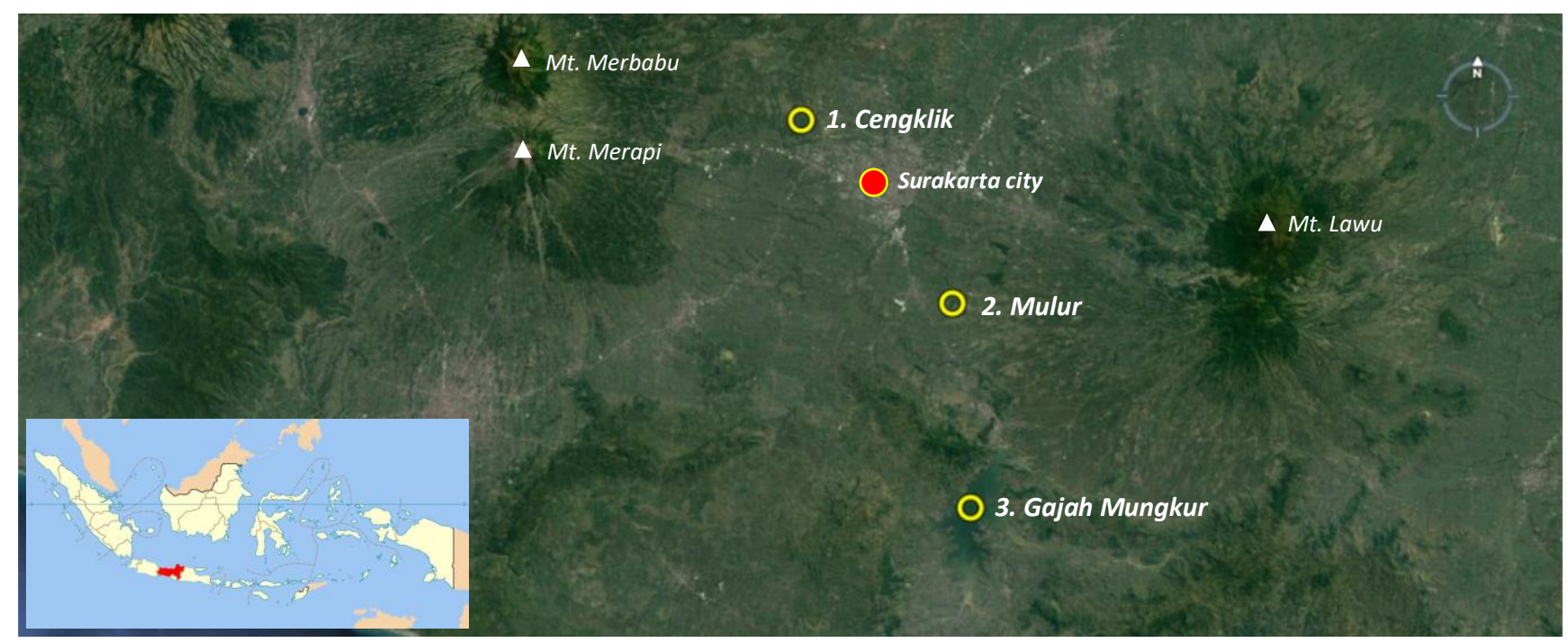

Figure 1. Map of Indonesia in the top and the study area at three reservoirs in Central Java, Indonesia. 1. Cengklik Reservoir, 2. Mulur Reservoir and 3. Gajah Mungkur Reservoir 


\section{Analysis of water physical and chemical parameters}

Water samples were collected from the depth of $60 \mathrm{~cm}$ from the surface using a water sampler. Water quality parameters such as dissolved oxygen, water temperature, conductivity, transparency, and $\mathrm{pH}$ were measured at the same places where fish samples were collected using multipurpose probes. The dissolved oxygen (mg/L) was measured using a digital oxygen meter (OXYGEN METER, Model DO-5510) while the water temperature $\left({ }^{\circ} \mathrm{C}\right)$ was measured by a thermometer. To measure the transparency, the Sachi disk was used $(\mathrm{cm})$. Electrical conductivity $(\mu \mathrm{s} / \mathrm{cm})$ was determined using a digital conductivity meter (Conductivity STARTER 300c, OHAUS). Water $\mathrm{pH}$ was measured using a $\mathrm{pH}$ meter $(\mathrm{pH}$ meter STARTER, OHAUS, version 300). A $600 \mathrm{ml}$ of water sample was collected from each zone then and transported to the chemical laboratory for total ammonia level analysis $(\mathrm{mg} / \mathrm{L})$ using the standard method for water analysis APHA (2017).

\section{Data analysis}

The obtained data were summarized in Microsoft Excel. The SPSS statistics program v. 21.0 was used for the comparison. Analysis of variance (ANOVA) followed by the least significant difference (LSD) test was employed to compare the data from the three reservoirs. Statistical significance was set at $(\mathrm{p}<0.01)$. The number of each parasite species and the total number of all parasites in each reservoir was calculated to determine the prevalence, mean abundance, and mean intensity, by using the mathematical calculations formulated by (Bush et al. 1997) as follows.

Prevalence $(\mathbf{P} \%)=\frac{\text { Number of infected with particular parasite species }}{\text { Total number of hostes examined }} \times 100$
Mean intensity $(\mathrm{MI})=\frac{\text { Total number of parasite species in host species }}{\text { Total number of infected hostes species }}$
Mean abundance $(\mathrm{MA})=\frac{\text { Total number of parasite species in host species }}{\text { Total number of examined hostes }}$

\section{RESULTS AND DISCUSSION}

The measures on physical and chemical parameters of water show that there are no significant differences among the three reservoirs in terms of dissolved oxygen (DO), $\mathrm{pH}$, water temperature, and ammonia concentration (Table 1). On the other hand, there is a significant difference at $\mathrm{p}<0.01$ in terms of conductivity and transparency with Cengklik reservoir had the highest conductivity and transparency with $251.00 \mu \mathrm{s} / \mathrm{cm}$ and $84.67 \mathrm{~cm}$, respectively. Overall, the mean values of physical and chemical parameters are within the permissible range for Nile tilapia fish culture in the cage systems APHA (2017).

We found that among 189 examined fish samples (63 samples from each reservoir), there were 110 females and 79 males (Table 2). The results on the examination of parasite infection show that Mulur reservoir had the highest total prevalence of infected fish with $90.4 \%$ of the fish were infected by parasites, while Gajah Mungkur reservoir had the lowest prevalence with $58.7 \%$ (Table 2). Accordingly, the Mulur reservoir had the highest total number of parasites with 1762, while Gajah Mungkur had the lowest with 391 parasites in total.

The results of the measurement on fish size show that no statistically significant differences among the mean values of measurements of total length, standard length, and weight taken from male or female fishes (Table 3). The results of the measurements of fishes show that males in Mulur reservoir had the highest mean total length of 20.33 $\mathrm{cm}$., while females in Gajah Mungkur reservoir had the lowest mean total length of $18.89 \mathrm{~cm}$ (Table 3). The results of the bodyweight of fishes show that males in the Cengklik reservoir had the highest mean body weight of 165.24 gram. Meanwhile females in the Gajah Mungkur reservoir had the lowest mean body weight of 149.21 gram (Table 3).

Table1. The results of physical and chemical parameters of water (mean \pm SD) at three reservoir sites in Central Java, Indonesia

\begin{tabular}{lcccc}
\hline \multicolumn{1}{c}{ Parameters } & \multicolumn{3}{c}{ Reservoir site } \\
\cline { 2 - 5 } & Cengklik & Mulur & Gajah Mungkur & Significant \\
\hline DO $(\mathrm{mg} / \mathrm{L})$ & $8.13 \pm 0.73$ & $7.63 \pm 0.38$ & $7.63 \pm 0.38$ & $\mathrm{NS}$ \\
Temperature $\left({ }^{0} \mathrm{C}\right)$ & $28.07 \pm 0.32$ & $28.70 \pm 0.26$ & $28.70 \pm 0.26$ & $\mathrm{NS}$ \\
Ammonia $(\mathrm{mg} / \mathrm{L})$ & $0.48 \pm 0.26$ & $1.13 \pm 0.08$ & $1.13 \pm 0.44$ & $\mathrm{NS}$ \\
Conductivity $(\mu \mathrm{s} / \mathrm{cm})$ & $251.00 \pm 18.50$ & $147.90 \pm 4.28$ & $147.90 \pm 4.28$ & $* *$ \\
Transparency $(\mathrm{cm})$ & $84.67 \pm 2.33$ & $59.00 \pm 1.73$ & $59.00 \pm 1.73$ & $* *$ \\
pH & $7.48 \pm 0.29$ & $7.10 \pm 0.08$ & $7.10 \pm 0.08$ & $\mathrm{NS}$ \\
\hline
\end{tabular}

Table 2. Comparison of parasitological data from the three reservoirs in Central Java, Indonesia

\begin{tabular}{lcccccc}
\hline \multicolumn{1}{c}{ Reservoir } & EF & Male & Female & IF/ non-IF & TP $(\%)$ & TNP \\
\hline Gajah Mungkur & 63 & 22 & 41 & $37 / 26$ & 58.7 & 391 \\
Mulur & 63 & 29 & 34 & $57 / 6$ & 90.4 & 1762 \\
Cengklik & 63 & 28 & 35 & $52 / 11$ & 82.5 & 1638 \\
Total & 189 & 79 & 110 & $146 / 43$ & & 3791 \\
\hline
\end{tabular}


*Note: EF: Examined fish, IF Infected fish, TP (\%): Total prevalence, TNP: Total number of parasites.

Table 3. The size of fish in terms of weight and length (mean $\pm \mathrm{SD}$ ) of males and females at the three reservoirs in Central Java, Indonesia

\begin{tabular}{lccc}
\hline \multicolumn{1}{c}{ Reservoir/ No. of samples } & TL $(\mathbf{c m})$ & SL $(\mathbf{c m})$ & FW $(\mathbf{g})$ \\
\hline Cengklik male $(\mathrm{n}=28)$ & $19.78 \pm 0.49$ & $16.20 \pm 0.41$ & $165.24 \pm 10.63$ \\
Cengklik female $(\mathrm{n}=35)$ & $19.72 \pm 0.46$ & $16.22 \pm 0.41$ & $173.60 \pm 11.71$ \\
Mulur male $(\mathrm{n}=27)$ & $20.33 \pm 0.52$ & $16.69 \pm 0.44$ & $176.84 \pm 10.68$ \\
Mulur female $(\mathrm{n}=34)$ & $19.69 \pm 0.55$ & $16.21 \pm 0.47$ & $167.96 \pm 11.52$ \\
Gajah Mungkur male $(\mathrm{n}=22)$ & $19.36 \pm 0.40$ & $16.08 \pm 0.32$ & $153.60 \pm 8.26$ \\
Gajah Mungkur female $(\mathrm{n}=41)$ & $18.89 \pm 0.42$ & $15.53 \pm 0.29$ & $149.21 \pm 8.33$ \\
Significant & $\mathrm{NS}$ & $\mathrm{NS}$ & NS \\
\cline { 2 - 2 }
\end{tabular}

*Note: TL: total length, SL: standard length, FW: fish weight, NS: no significant differences

Table 4. The number of parasite infections (mean \pm SD) in gills, fins, and the skin of examined fishes across sexes at the three reservoirs in Central Java, Indonesia

\begin{tabular}{lcccc}
\hline \multicolumn{1}{c}{ Reservoir/ no. of samples } & Gills & Fins & Skin & Total \\
\hline Cengklik male $(\mathrm{n}=28)$ & $2.20 \pm 0.58$ & $3.20 \pm 8.78$ & $11.07 \pm 3.55$ & $16.47 \pm 4.94$ \\
Cengklik female $(\mathrm{n}=35)$ & $4.86 \pm 2.55$ & $8.83 \pm 2.83$ & $19.43 \pm 6.45$ & $33.11 \pm 8.58$ \\
Mulur male $(\mathrm{n}=27)$ & $4.41 \pm 1.54$ & $4.33 \pm 1.23$ & $11.37 \pm 3.14$ & $20.11 \pm 4.34$ \\
Mulur female $(\mathrm{n}=34)$ & $3.56 \pm 1.01$ & $4.65 \pm 1.76$ & $27.21 \pm 10.18$ & $35.41 \pm 11.84$ \\
Gajah Mungkur male $(\mathrm{n}=22)$ & $1.00 \pm 0.47$ & $1.59 \pm 0.73$ & $1.64 \pm 0.74$ & $4.23 \pm 1.31$ \\
Gajah Mungkur female (n=41) & $1.85 \pm 0.75$ & $2.73 \pm 1.28$ & $2.68 \pm 0.90$ & $7.27 \pm 2.20$ \\
Significant & NS & NS & $* *$ & $* *$ \\
\hline
\end{tabular}

*Note: $\mathrm{n}$ : number of examined fish 63/ reservoir, **: significant differences at $\mathrm{P}<0.01$, NS: no significant differences

Table 5. The species of parasite, and the prevalence, mean intensity and mean abundance of each parasite at the three reservoirs in Central Java, Indonesia

\begin{tabular}{|c|c|c|c|c|c|c|c|c|c|}
\hline \multirow{3}{*}{ Parasites species } & \multicolumn{9}{|c|}{ Reservoir } \\
\hline & \multicolumn{3}{|c|}{ Gajah Mungkur } & \multicolumn{3}{|c|}{ Mulur } & \multicolumn{3}{|c|}{ Cengklik } \\
\hline & $\mathbf{P}(\%)$ & MI & MA & $\mathbf{P}(\%)$ & MI & MA & $\mathbf{P}(\%)$ & MI & MA \\
\hline Tetrahymena corlissi & 0 & 0 & 0 & 11.1 & 1.8 & 0.2 & 0 & 0 & 0 \\
\hline Apiosoma spp. & 17.4 & 1.5 & 0.26 & 1.2 & 1.6 & 0.23 & 7.9 & 1.4 & 0.1 \\
\hline Trichodina spp. & 50.7 & 11 & 5.6 & 82.5 & 32.7 & 27 & 73 & 34.8 & 25.4 \\
\hline Ichthyophthirius multifiliis & 0 & 0 & 0 & 0 & 0 & 0 & 15.8 & 1.6 & 0.2 \\
\hline Cryptobia spp. & 6.3 & 1.7 & 0.1 & 3.1 & 3 & 0.09 & 3.1 & 2 & 0.06 \\
\hline Chilodonella spp. & 4.7 & 4.3 & 0.2 & 12.6 & 3.2 & 0.4 & 7.9 & 1.2 & 0.09 \\
\hline Ambiphrya spp. & 0 & 0 & 0 & 0 & 0 & 0 & 4.7 & 1.6 & 0.07 \\
\hline
\end{tabular}

*Note; P: Prevalence, MI: Mean intensity, MA: Mean abundance, TNP: Total number of parasites

The results found that there is no significant difference $(\mathrm{p}<0.01)$ in the number of parasitic infections in gills and fins of males and females across the three reservoirs (Table 4). Conversely, there was a significant difference $(\mathrm{p}<0.01)$ in the number of parasitic infections in the skin and the total number of parasites between males and females from the three reservoirs. The results of the mean values of the total number of parasites show that females in Mulur reservoir had the highest mean values of the total number of parasites 35.41, while males in the Gajah Mungkur reservoir had the lowest mean values of the total number of parasites 4.23 (Table 4). Accordingly, the females had the highest mean values of parasites than males in the three reservoirs in gills, fins, and skin with $4.86,8.83$, and 27.21 respectively.
A detailed examination of the prevalence of parasite infections is presented in Table 5. We found that Trichodina spp. was the most prevalent parasite across the three reservoirs. A similar result was shown by Indahsari et al. (2019) on cultured Nile tilapia in Indonesia that Trichodina spp. was the most common parasite among the other parasite species in their study. In our study, the prevalence of Trichodina spp. was the highest at the Mulur reservoir $(82.5 \%)$ with a mean intensity of 32.7 and a mean abundance of 27 (Table 5). The second-highest prevalence was recorded at the Cengklik reservoir (73\%) with a mean intensity and mean abundance of 34.8 and 25.4, respectively. The lowest prevalence was recorded in the Gajah Mungkur reservoir $(50.7 \%)$ with a mean intensity of 11 and a mean abundance of 5.6. 
Human activities in and around the reservoirs might cause poor water quality due to the accumulation of high organic matter load which favors the reproduction and proliferation of Trichodina spp. The protozoan parasite Trichodina spp. in water bodies is an indicator of poor water quality. Thus, further seasonal studies should be done in those reservoirs considering abiotic and biotic factors such as stocking fish density, nutrients, and other water quality parameters.

The protozoan Apiosoma spp. was observed at the three reservoirs from the gills of the Nile tilapia. This ciliated protozoan was recorded at the Gajah Mungkur reservoir with a prevalence of $17.4 \%$, and mean intensity and mean abundance of 1.5 and 0.26, respectively. At Cengklik reservoir, it was recorded with the prevalence of $7.9 \%$, mean intensity and mean abundance of 1.4 and 0.1 , respectively. The lowest prevalence $(1.2 \%)$ was recorded at Mulur reservoir with a mean intensity of 1.6 and a mean abundance of 0.23 . The infection by Apiosoma spp. in gills could result in disrupting gas exchange through the respiratory epithelium, and then mortalities following massive colonization of the gills. However, the recorded prevalence in this study was lower than that reported for the same host grown in Costa Rica with a prevalence of $84 \%$ in the dry season and $100 \%$ in the rainy season (Arguedas et al. 2017). Moreover, the recorded prevalence's in this study was lower than that reported prevalence with $28.2 \% \%$ from freshwater fish in West Azerbaijan, northwest of Iran by (Ebrahimi et al. 2018).

The ciliated protozoan Ichthyophthirius multifiliis was observed only at the Cengklik reservoir in the gills and the skin with a prevalence of $15.8 \%$, a mean intensity of 1.6 , and a mean abundance of 0.2 (Table 5). Generally, this parasite infects the gills and skin of fish and causes 'Ich' or white spot disease and causes high mortality rates in both cultured and wild populations of fish. Poor water quality and fish stress are critical factors for the spread of this parasite on Nile tilapia. The current investigation revealed that this parasite was recorded from the gills and skin of the fish that weighed between 220-245g and total length between $23-25 \mathrm{~cm}$. A similar study was recorded by Alves et al.(2000) who indicated I. multifiliis isolated from gills of $O$. niloticus was positively correlated with weight and lengths of fish. However, the differences in the occurrence of this parasite for the same host between the different reservoirs may be due to the balance between the performance of the parasites and the host immune system.

Chilodonella spp. was found at all three reservoirs from the skin and gills of Nile tilapia. Furthermore, this parasite recorded the highest prevalence at reservoir Mulur (12.6 $\%$ ) with a mean intensity of 3.2 and a mean abundance of 0.4. This was followed by a prevalence of $7.9 \%$ at Cengklik reservoir with a mean intensity of 1.2 and mean abundance of 1.2. Meanwhile, the lowest prevalence (4.7 $\%$ ) was recorded at reservoir Gajah Mungkur with a mean intensity of 4.3 and a mean abundance of 0.2. However, the recorded prevalence by Chilodonella spp. in this study was lower than the recorded prevalence by (Banu and Khan 2004) who indicated that the prevalence of Chilodonella spp. was $24.2 \%$ in July and $16.7 \%$ in June. Moreover, our recorded prevalence was higher than the recorded prevalence of $3 \%$ in the dry season and lower than the recorded prevalence of $61 \%$ in the rainy season by (Arguedas et al. 2017).

The protozoan Ambiphrya spp. was recorded only at the reservoir Cengklik from the gills of Nile tilapia. The recorded prevalence was $4.7 \%$, with a mean intensity of 1.6, and a mean abundance of 0.07. A similar species of this parasite was isolated from the same host Nile tilapia in Saudi Arabia (Abdel-Baki et al. 2014). Moreover, this parasite also was recorded from Nile tilapia in Egypt (Ashmawy et al. 2018). However, this is the first record of this parasite from cultured Nile tilapia in Central Java.

The flagellated protozoan Cryptobia spp. was recorded in all three reservoirs from the gills, skin, and fins. The recorded prevalence was $6.3 \%, 3.1 \%$ and $3.1 \%$ at Gajah Mungkur, Mulur and Cengklik, respectively. The mean intensity recorded were 1.7 at Gajah Mungkur, 3 at Mulur, and 2 at Cengklik. While the mean abundance recorded were 0.1, 0.09, and 0.06 at Gajah Mungkur, Mulur, and Cengklik. However, some species of this parasite are pathogenic for fish, especially fingerling (Bruno et al. 2006). Thus, further attention should be given to control this parasite.

The ciliate protozoan Tetrahymena corlissi was observed just in the Mulur reservoir from the gill of the Nile tilapia. The recorded prevalence was $11.1 \%$ with a mean intensity of 1.8 and a mean abundance of 0.2 . However, this parasite has been reported from a variety of freshwater fish species, and the infection may cause general debilitation, skin hemorrhage, and exophthalmia to both tropical and temperate species (Bruno et al. 2006).

In this study seven species of ectoparasites were identified namely: Tetrahymena corlissi, Apiosoma spp., Trichodina spp., Cryptobia spp., Chilodonella spp., Ambiphrya spp., and Ichthyophthirius multifiliis from the gills, fins, and skin of Nile tilapia. The output from the study showed a significant difference at $p<0.01$ in the total number of parasites among the reservoirs. The total number of ectoparasitic protozoa was the highest at Mulur reservoir compared to the other two reservoirs (Cengklik and Gajah Mungkur). That means the location of the reservoir affects the occurrence of ectoparasitic protozoa. The water in the reservoir Mulur was not suitable for drinking because of human activities around the reservoir in contrast to the Gajah Mungkur reservoir. Although the physical and chemical parameters were within the optimum range for Nile tilapia culture under the cage system, controlling water quality could be challenging in open waters. Sustainable management for fishes should consider abiotic factors such as water quality conditions and other biotic factors to maintain the health of Nile tilapia. The infestation level of ectoparasitic protozoa in this study arguably will not pose a significant threat to the Nile tilapia in the cages since no fish mortality was observed. However, critical attention should be given to the cages by employing good management practices to prevent disease outbreaks caused by the protozoan parasites. Hence, the findings from this research can be used for more effective 
control measures of parasitic infestation in cage systems at these reservoirs.

\section{ACKNOWLEDGEMENTS}

The authors thank the head of the Bioscience Department, Laboratory of Biology, MIPA Integrated Lab., and Central Lab at the Sebelas Maret University, Indonesia for providing necessary laboratory facilities. We also gratefully acknowledge the financial assistance from KNB Scholarship (M.Sc. scholarship) awarded to Waleed Krpos. We are very grateful to Balai Besar Wilayah Sungai Bengawan Solo (BBWSBS) staff for providing the necessary facilities to collect the fish samples.

\section{REFERENCES}

Abdel-Baki AAS, Gewik MM, Al-Quraishy S. 2014. First records of Ambiphrya and Vorticella spp. (Protozoa, Ciliophora) in cultured Nile tilapia (Oreochromis niloticus) in the central region of Saudi Arabia. Saudi J Biol Sci 21 (6): 520-523. DOI: 10.1016/j.sjbs.2014.01.002.

Alves DR, Luque JL, Paraguassú AR. 2000. Ectoparasitos da Tilápia nilótica Oreochromis niloticus (Osteichthyes: Cichlidae) da Estaçâo de Piscicultura da UFRRJ. Rev Univ Rural Ciênc Vida 22: 81-85.

APHA, AWWA, WEF. 2017. 3120 B. Inductively Coupled Plasma (ICP) method. Standard Methods for the Examination of Water and Wastewater, American Public Health Association, Washington DC.

Arguedas CD, Ortega SC, Martínez CS, Astroza CA. 2017. Parasites of Nile Tilapia larvae Oreochromis niloticus (Pisces: Cichlidae) in concrete ponds in Guanacaste, Northern Costa Rica. UNED Res J 9 (2): 313-319. DOI: $10.22458 /$ urj.v9i2.1904.

Ashmawy K, Hiekal F, AboAkadda S, Laban N. 2018. The interrelationship of water quality parameters and fish parasite occurrence. Alexandria J Vet Sci 59 (1): 97-106. DOI: 10.5455/ajvs.299584.

Banu ANH, Khan MH. 2004. Water quality, stocking density, and parasites of freshwater fish in four selected areas of Bangladesh. Pak J Biol Sci 3 (1028-8880): 436-440. DOI: 10.3923/pjbs.2004.436.440.
Biu AA, Diyaware MY, Yakaka W, Joseph E. 2014. Survey of parasites infesting the Nile tilapia (Oreochromis niloticus) from. Niger J Fish Aquac 2: 6-12.

Bruno DW, Nowak B, Elliott DG. 2006. Guide to the identification of fish protozoan and metazoan parasites in stained tissue sections. Dis Aquat Org 70 (1-2): 1-36.

Bush AO, Lafferty KD, Lotz JM, Shostak AW. 1997. Parasitology meets ecology on its terms: Margolis et al. Revisited. J Parasitol 83 (4): 575583. DOI: $10.2307 / 3284227$.

Ebrahimi M, Nematollahi A, Samiei A, Golabi M. 2018. Ectoparasitism on freshwater fish in West Azerbaijan, northwest of Iran. Comp Clin Pathol 27 (2): 353-356. DOI: 10.1007/s00580-017-2598-9.

Indahsari M, Kismiyati, Ulkhaq MF. 2019. Prevalence and Intensity of ectoparasites of Tilapia (Oreochromis niloticus) in ponds with low, medium, and high stocking density. IOP Conf Ser: Earth Environ Sci 236 (1): 012108. DOI: 10.1088/1755-1315/236/1/012108.

Kuchta R, Basson L, Cook C, Fiala I, Bartošová-Sojková P, Řehulková E. 2018. A systematic survey of the parasites of freshwater fishes in Africa. In: Scholz T, Vanhove MPM, Smit N, Jayasundera Z, Gelnar M (eds). A Guide to the Parasites of African Freshwater Fishes. Abc Taxa, Belgium

Mitiku MA, Konecny R, Haile AL. 2018. Parasites of Nile tilapia (Oreochromis niloticus) from selected fish farms and Lake Koftuin central Ethiopia. Ethiopian Vet J 22 (2): 65. DOI: 10.4314/evj.v22i2.6

Molnar K, Szekely C, Lang M. 2019. A Field Guide to Warm Water Fish Diseases in Central and Eastern Europe, the Caucasus, and Central Asia. FAO Fisheries and Aquaculture Circular, Ankara, Turkey.

Pantoja WM, Neves RL, Dias RM, Marinho GR, Montagner D, Tavaresdias M. 2012. Protozoan and metazoan parasites of Nile tilapia Oreochromis niloticus cultured in Brazil. Rev MVZ Córdoba 17 (1): 2812-2819.

Santos R, Pabon A, Silva W, Silva H, Pinho M. 2020. Population structure and movement patterns of blackbelly rosefish in the NE Atlantic Ocean (Azores archipelago). Fish Oceanogr 29 (3): 227-237. DOI: 10.1111/fog. 12466 .

Suliman EAM, Al-Harbi AH. 2016. Prevalence and seasonal variation of ectoparasites in cultured Nile tilapia Oreochromis niloticus in Saudi Arabia. J Parasit Dis 40 (4): 1487-1493. DOI: 10.1007/s12639-0150717-6.

Tran N, Rodriguez UP, Chan CY, Phillips MJ, Mohan CV, Henriksson PJG, Koeshendrajana S, Suri S, Hall S. 2017. Indonesian aquaculture futures: An analysis of fish supply and demand in Indonesia to 2030 and role of aquaculture using the AsiaFish model. Mar Policy 79: 2532. DOI: 10.1016/j.marpol.2017.02.002. 